\title{
Effect of Vermicompost on the Growth Performance of Indian Major Carps in Fish Rearing Pond
}

Suresh Kumar* and Sunita Godara

CRM Jat (P. G.) College, Hisar - 125001, Haryana, India; suresh_sang@yahoo.com

\begin{abstract}
Different organic manures vermicompost @ 15000, vermicompost @ 10000, cow dung @ 10000, poultry manure @ 6000, pig manure @ $4000 \mathrm{~kg} / \mathrm{ha} / \mathrm{yr}$ and control used to monitored their effect on growth performance of Catla catla, Labeo rohita and Cirrhinus mrigala. The results revealed that all the three species gained maximum length in vermicompost @ 10,000 kg/ha/yr followed by vermicompost @ 15,000 kg/ha/yr, cow dung @ 10,000 kg/ha/yr, poultry manure @ 6,000 kg/ha/yr, pig manure @ 4,000 kg/ha/yr and control. Among the 3 species C. mrigala showed maximum increase in body length which was $33.4 \mathrm{~cm}$ followed by L. rohita and C. catla was $32.1,31.3 \mathrm{~cm}$ in vermicompost @ 10,000 kg/ha/yr treatment. The minimum length of C. mrigala, L. rohita, C. catla observed in pond treated control. But in case of $C$. mrigala, the result revealed that the maximum increase in body length in vermicompost $>$ poultry manure > cow dung > pig manure and control, respectively. All the three species gained maximum growth in vermicompost. Among the 3 species L. rohita showed maximum growth followed by $C$. catla and C. mrigala. There was two times more growth of Indian major carps in pond treated with vermicompost @ 10,000 kg/ha/yr as compared to control.
\end{abstract}

Keywords: Carp, Growth, Manure, Poultry, Vermicompost

\section{Introduction}

Fisheries sector is very important not only as a main source of animal protein to ensure food security (Sheikh and Sheikh, 2004) but also to improve employment and income for poverty elimination in developing countries like India. The most important freshwater culture able fishes of India are the major Indian carps like Catla catla, Labeo rohita and Cirrhinus mrigala. Some exotic species such as Cyprinus carpio, Ctenopharyngodon idella and silver carp Hypophthalmichthys molitix are also introduced in India. However common combinations of fish for composite fish culture system are L. rohita, C. catla and C. mrigala ${ }^{8}$. Fish production can be increased treatment by feeding and pond fertilization. Optimum fertilization rate is the amount of organic matter that can be cost effective and utilized in a pond ecosystem without having harmful effect on water quality as well as on fish growth ${ }^{5}$. Supplementary feeding plays an important role in intensive and semi-intensive fish culture system. Pond fertilization is a management protocol to enhance biological productivity using both organic manure and inorganic fertilizers ${ }^{7}$. Fertilization of a fish pond actually increases the production of beneficial phytoplankton, microscopic free-floating algae that act as the basis of the aquatic food chain which, in turn increases the amount of harvestable fish $\stackrel{8}{ }$. In some cases, one species enhances the food availability for other species and thus increases the total fish yield per unit area $22,2,18$. When organic fertilizers decompose in the water, varying amounts of nitrogen, phosphorous and potassium $(\mathrm{N}, \mathrm{P}, \mathrm{K})$ are released which serves as primary nutrients for the phytoplankton community. Organic fertilization also stimulates the growth of decomposers such as bacteria and fungi. Bacteria and fungi are critical to the breakdown of the toxic waste products that can accumulate with the use of prepared feeds $\frac{10,29}{}$. However, animal manure takes some time for its decomposition and release of nutrients in the body of water $\stackrel{24}{ }$. Beside this, higher doses as well as high ambient temperature may make the water body unsuitable for fish culture by adversely altering its hydro-biological characteristics $\frac{25}{}$. The effects of poultry manure, digested sewage sludge cake and cow-dung on plankton production and fish growth were evaluated. Both plankton production and fish growth (C. catla and C. carpio var. communis) were found to be highest in the poultry manure treatment, followed by the sludge cake and cow dung treatments. Compared with the cow

*Author for correspondence 
dung treatment, total fish production was $50.6 \%$ more in the poultry manure and $19.0 \%$ more in the sludge-cake treatment. In terms of dry weight of the manures, the fertilizer (manure) coefficients fertilizer $(\mathrm{kg}) /$ fish production $(\mathrm{kg})$ were 5.2, 6.6 and 7.8, respectively, for poultry manure, sludge cake and cow dung 3 .

\section{Materials and Methods}

\subsection{Experimental Set Up/Design}

A series of experiments were carried out using earthen ponds with the size of $20 \mathrm{ft} \times 22 \mathrm{ft}$. Six different treatments with four replication were maintained in ponds. To fertilize the ponds, semi dried pig manure @ 4,000 kg/ha/yr $\left(\mathrm{T}_{2}\right)$, poultry manure @ 6,000 kg/ha/yr $\left(\mathrm{T}_{3}\right)$, cow dung @10,000 kg/ha/yr $\left(\mathrm{T}_{4}\right)$, vermicompost @10,000 kg/ha/yr ( $\left.\mathrm{T}_{5}\right)$, vermicompost @ 15,000 $\mathrm{kg} / \mathrm{ha} / \mathrm{yr}\left(\mathrm{T}_{6}\right)$ and control $\left(\mathrm{T}_{1}\right)$ were applied at $25 \%$ initial and remaining split doses were given at biweekly intervals in ponds. Fingerlings were acclimatized in aquarium for 10 days prior to the commencement of experiment. During the acclimatization period, the fry were fed on supplementary diet. Fry with mean body weight ranging between 0.82 to 1.42 g were randomly distributed @ 30 fish per pond in 3:4:3 ratios with four replication of each treatment. All fish were fed daily twice@ $2 \% \mathrm{BWd}^{-1}$ for the whole experimental duration of 12 months. Fish growth was monitored after regular 15 days interval in term of weight and length gain and feeding rate adjusted accordingly. At the end of the experiment, the growth variables including weight and length from all the treatments were recorded individually and processed for subsequent analysis according to (APHA, 1998).

\subsection{Estimation of Growth Parameters}

\subsubsection{Live Weight Gain}

Weight gain was measured in terms of differences between final weight and Initial weight.

Where,

$$
\text { Weight gain }=\left(\mathrm{W}_{2}-\mathrm{W}_{1}\right)
$$

$$
\begin{aligned}
& \mathrm{W}_{1}=\text { Initial weight }(\mathrm{g}) . \\
& \mathrm{W}_{2}=\text { Final weight }(\mathrm{g}) .
\end{aligned}
$$

\subsubsection{Percent Weight Gain}

$$
\begin{aligned}
& \text { Percent weight gain }(\%) \\
& =\frac{\text { Final body weight }(\mathrm{g}) \text {-Initial body weight }(\mathrm{g})}{\text { Initial body weight }(\mathrm{g})} \times 100
\end{aligned}
$$

\subsubsection{Specific Growth Rate}

Specific growth rate (\% wt gain/day)

$=\frac{\text { In final body weight }(\mathrm{g})-\text { In initial body weight }(\mathrm{g})}{\text { Culture period }(\text { days })} \times 100$

\subsubsection{Live Length Gain}

Length was measured in terms of differences between final length and initial length.

Where,

$$
\text { Length gain }=\left(\mathrm{L}_{2}-\mathrm{L}_{1}\right)
$$

$$
\begin{aligned}
& \mathrm{L}_{2}=\text { Final length }(\mathrm{cm}) \\
& \mathrm{L}_{1}=\text { Initial length }(\mathrm{cm})
\end{aligned}
$$

\subsubsection{Statistical Analysis}

The obtained results were analyzed statistically using Completely Randomized Design (CRD) to evaluate differences among different treatments means at 0.05 significance level ${ }^{27}$.

\section{Results and Discussion}

In India, agriculture and livestock work in integration, where livestock waste is the most commonly used organic manure in agriculture and aquaculture. Hence, the small scale on farm integration of vermicomposting of livestock and agriculture waste with the rural aquaculture holds ample scope for developing economically and ecologically sustainable farming system for the socio-economic upliftment of rural population in developing countries ${ }^{21}$. In the present investigation the body weight of C. catla, L. rohita and C. mrigalain vermicompost $@ 10,000 \mathrm{~kg} / \mathrm{ha} / \mathrm{yr}$ was found to be maximum increase as compared to vermicompost @ 15,000 cow dung @ 10,000 poultry manure @ 6,000 and pig manure @ 4,000 kg/ha/ yr. It was found that mean weight of all these species were increased in first two months i.e. September and October but decreased during November to February due to cold conditions of weather. The body length of C. catla, L. rohita and C. mrigala increased maximum in September and October in vermicompost $>$ cow dung $>$ poultry manure $>$ pig manure and less in control (Table 1). From these results, it seemed that vermicompost @10,000 better than, vermicompost @15,000, cow dung@10,000, poultry manure @ 6,000 and pig manure @ 4,000 kg/ha/yr. Bansal (2010) reported that growth of common carp was higher in fertilized pond with the provision of supplemental feed than in control. Deolalikar and Mitra (2004) have reported comparable efficacy of vermicompost with other commercial manures used in aquaculture. Vermicompost has also been reported to result in higher survival and growth of aquatic organisms including fish and prawn (Kumar et al., 2007) without adversely affecting the water quality. The slow 
growth rate (gm) of C. catla, L. rohita and C. mrigala during the start of experiment November to February under the enrichment of all the treatments was because of low water temperature. The marked increase in water temperature was observed after February, which was responsible to accelerate decomposition of organic inputs (poultry, pig manure and cow dung). During these warm months the release of $\mathrm{CO}_{2}$ for photosynthesis was maximum, which enhanced the planktonic biomass. Javed et al. (1990) also observed that manure increases the weight, fork length and total length of C. catla, L. rohita and C. mrigala. Organic manuring proves to benefit the farmer economically as it serves to reduce $50 \%$ cost of inorganic fertilizer and supplementary feed (Yadava and Garg, 1992). Banergee et al. (1979) reported that poultry manure can maximize fish production as it can provide nitrogen and phosphorous adequately for phytoplankton and zooplankton which in turn serve as food items for fish. Kongombe et al. (2006) agree that the use of chicken manure produce better results than cattle and pig manure treatments in unfertilized ponds. They obtained significantly higher yield of Tilapia rendalli in chicken manure treatment than those of cattle manure and pig manure along with large amount of chlorophyll a and large number of zooplanktons. However, Rappaport and Sarig (1978) claimed that the feed of cow dung for fish culture produced highly positive results compared to poultry droppings which confirms present finding. In enriched fish ponds with cow dung carps fingerlings grow much better than ponds enriched fish ponds with inorganic fertilizers as suggested by Machaodo and Costagonlli (1979).

The value of Specific Growth Rate (SGR) in pig manure @ 4,000 kg/ha/yr and poultry manure @ 6,000 kg/ha/yr was found to be maximum 8.93, 9.90 and $10.06 \%$ per day in September and 1.53, 1.47 and $1.40 \%$ per day moderate in October. It was found low during November to February in treatments $1.33,1.23,0.37$ and $0.64 \%$ per day in control. The SGR in treatment cow dung @ 10,000 kg/ha/yr maximum in September $10.63 \%$ per day and remained same around 1.03 , 1.20 to $1.30 \%$ per day from October to December. This value of SGR was increased up to 1.67 to $1.71 \%$ per day, during January to February. In the month of March and April, it lowered down to 1.37 to $1.00 \%$ per day followed by $0.77,0.56,0.40$ and $0.26 \%$ per day till the end of study period i.e. August, respectively (Table 2). It was noticed that at the start of September the SGR in vermicompost @ 10,000 and vermicompost @ 15,000 kg/ ha/yr was 10.56 and $10.26 \%$ per day. But the value of SGR increased in vermicompost @ 10,000 kg/ha/yr to 1.77 to 1.83 $\%$ per day during October to November.

The value of $L$. rohita SGR in control, pig manure @ 4,000 $\mathrm{kg} / \mathrm{ha} / \mathrm{yr}$ and poultry manure @ 6,000 kg/ha/yr was found to be maximum in September 8.56, 9.40 and 10.73\% per day. The second half of study period exhibit slightly moderate increase in value of SGR in treatments control, pig manure @ 4,000 kg/ ha/yr and poultry manure @ 6,000 kg/ha/yr i.e. 1.30, 1.40 and $1.00 \%$ per day (Table 2). Increase in mean relative weight in vermicompost @ 10,000 kg/ha/yr and vermicompost @ 15,000 $\mathrm{kg} / \mathrm{ha} / \mathrm{yr}$ showed maximum in October 76.76 and $64.74 \%$. But gradually declined in later months i.e. 81.53 and $71.59 \%$ November, 82.03 and 72.80 \% December, 33.59 and $46.36 \%$ January, 34.50 and $34.40 \%$ February, 22.77 and 30.37\% March, 20.65 and $23.90 \%$ April, 22.09 and $17.15 \%$ May, 14.05 and $14.25 \%$ June, 14.09 and $15.25 \%$ July, 11.58 and $12.16 \%$ in August as shown in Table 3.

The value of C. mrigala SGR in control, pig manure @ 4,000 $\mathrm{kg} / \mathrm{ha} / \mathrm{yr}$ and poultry manure @ 6,000 kg/ha/yr was found to be maximum 5.96, 7.40 and $8.06 \%$ per day in September and $1.60,1.40$ and $1.33 \%$ per day moderate in October. It was found low during November to January, $1.53,1.13$ and $0.40 \%$ per day in control, 1.23, 1.13 and $0.40 \%$ per day in pig manure @ 4,000 $\mathrm{kg} / \mathrm{ha} / \mathrm{yr}$ and $1.03,1.00$ and $0.63 \%$ per day in poultry manure @ 6,000 kg/ha/yr. It was noted that from October to February the values of mean relative weight slightly increase was 35.34 , 29.64, 29.64, 29.97 and $31.53 \%$ per day and decrease $24.06 \%$ per day in March. Mean relative weight increase was declined during the last quarter of study period from April to August i.e. 67.20, 58.04, 44.67, 19.63 and $18.71 \%$ per day (Table 3). SGR of C. mrigala weight with respect to vermicompost @10,000 $\mathrm{kg} / \mathrm{ha} / \mathrm{yr}$ and vermicompost @ 15,000 kg/ha/yr was calculated. It was noticed that at the start of September the SGR 10.36 and $10.80 \%$ per day in vermicompost @ 10,000 kg/ha/yr and vermicompost @ 15,000 kg/ha/yr. But this value of SGR increased in vermicompost @ 10,000 kg/ha/yr to 1.67, 1.87 to $1.87 \%$ per day (Table 2). Kaur and Ansal (2010) also conducted an experiment in cemented tanks $(0.002 \mathrm{ha})$ for 120 days to assess the efficacy of vermicompost as fish pond manure at a dose of $10,000 \mathrm{~kg} / \mathrm{ha} / \mathrm{yr}\left(\mathrm{VC}_{10}\right), 15,000 \mathrm{~kg} / \mathrm{ha} / \mathrm{yr}\left(\mathrm{VC}_{15}\right)$ and $20,000\left(\mathrm{VC}_{20}\right) \mathrm{kg} / \mathrm{ha} / \mathrm{yr}$ in comparison to semi-digested cow dung (8-10 days old), which was utilized at a dose of 20,000 $\mathrm{kg} / \mathrm{ha} / \mathrm{yr}\left(\mathrm{CD}_{20}\right)$ and found suitable for fish growth. The gain in the live body weight of C. catla in vermicompost @ 10.000 $\mathrm{kg} / \mathrm{ha} / \mathrm{yr}$ was observed to be maximum with 899.1 followed by 879.2 in vermicompost @ 15,000 kg/ha/yr, 834.5 in cow dung @ 10,000 kg/ha/yr, 767.1 in poultry manure @ 6,000 kg/ha/yr and $716.9 \mathrm{gm}$ in pig manure @ 4,000 kg/ha/yr. Above all these five treatments were found to have more growth promoting effect over the $644.2 \mathrm{gm}$ in control (Table 4). The mean values of gain in live body length of C. catla in all the six treatments were also found to be different. The gain in the live body length of C. catla in vermicompost @ 10,000 kg/ha/yr was observed to be maximum with 31.3 followed by 29.4 in vermicompost @ $15,000 \mathrm{~kg} / \mathrm{ha} / \mathrm{yr}, 25.9$ in cow dung @ 10,000 kg/ha/yr, 24.1 in poultry manure@6,000 kg/ha/yr, 22.3 in pig manure @ 4,000 $\mathrm{kg} / \mathrm{ha} / \mathrm{yr}$ and $19.4 \mathrm{~cm}$ in control. 


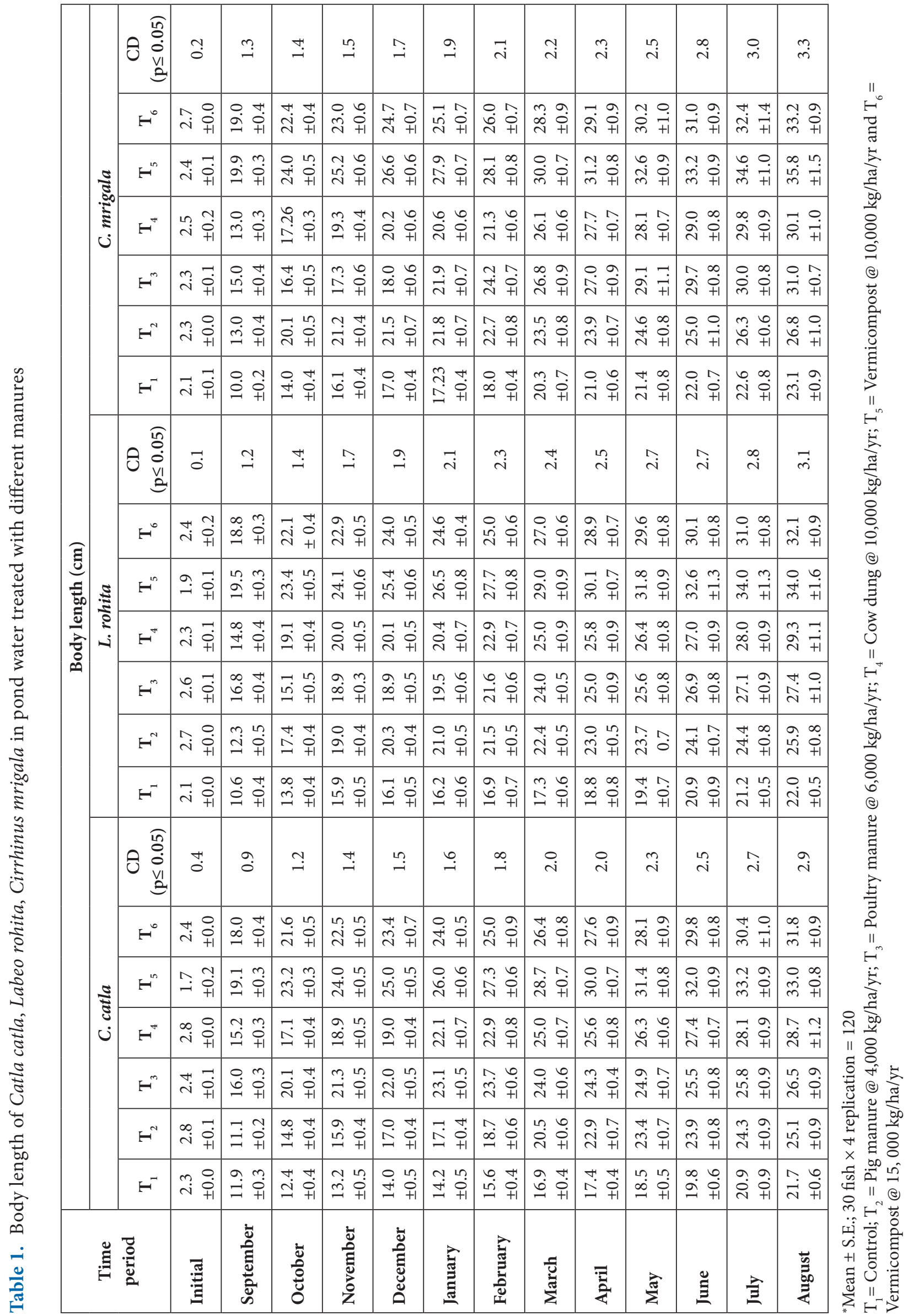




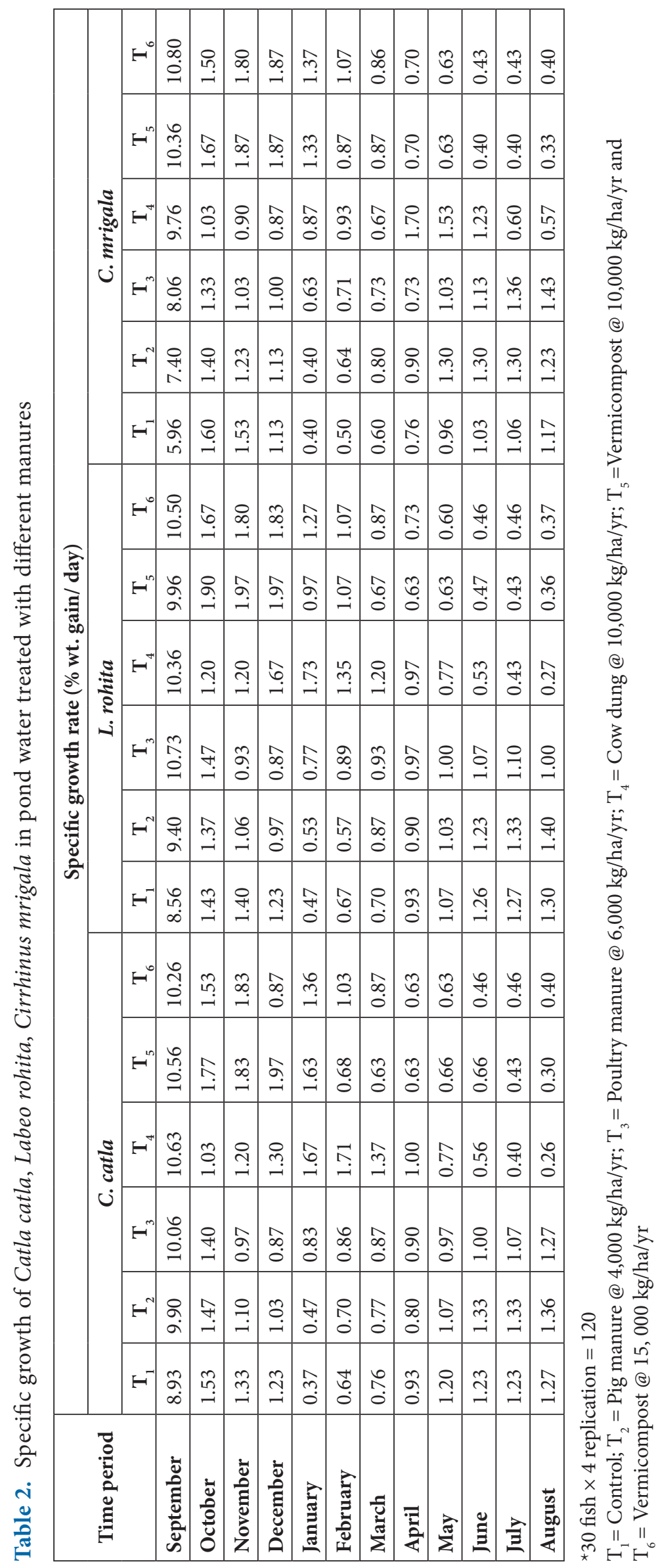




\begin{tabular}{|c|c|c|c|c|c|c|c|c|c|c|c|c|c|}
\hline & & $=\begin{array}{c}J \\
0 \\
\infty \\
i n\end{array}$ & $\begin{array}{l}\stackrel{2}{0} \\
\stackrel{i}{N}\end{array}$ & $\mid \begin{array}{c}\stackrel{n}{7} \\
\stackrel{+}{N}\end{array}$ & $\mid \begin{array}{l}\tilde{\alpha} \\
\alpha \\
\alpha\end{array}$ & $\begin{array}{l}\vec{b} \\
\dot{d} \\
m\end{array}$ & $\begin{array}{c}m \\
\stackrel{\sim}{n}\end{array}$ & 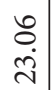 & $\mid \begin{array}{l}\vec{J} \\
\dot{\sim}\end{array}$ & $\mid \begin{array}{c}\infty \\
\stackrel{2}{\sim} \\
\sim\end{array}$ & $\mid \begin{array}{c}\stackrel{2}{n} \\
\stackrel{m}{-}\end{array}$ & $\begin{array}{l}\stackrel{\infty}{\infty} \\
\stackrel{\Xi}{\Xi}\end{array}$ & \\
\hline & & 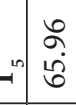 & $\underset{N}{\stackrel{J}{N}}$ & 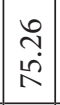 & 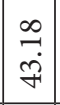 & $\begin{array}{c}n \\
\hat{n} \\
\stackrel{n}{n}\end{array}$ & 苦 & 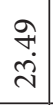 & $\begin{array}{c}\stackrel{N}{\vec{i}} \\
\vec{\sim}\end{array}$ & 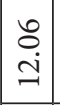 & $\begin{array}{l}\stackrel{0}{0} \\
\stackrel{-}{2}\end{array}$ & $\begin{array}{l}\vec{b} \\
\dot{a} \\
\end{array}$ & \\
\hline & & $=\mid \begin{array}{l}\vec{m} \\
\dot{m} \\
m\end{array}$ & ते & $\mid \begin{array}{r}\mathbf{b} \\
\dot{a} \\
\grave{i}\end{array}$ & $\begin{array}{l}\hat{\alpha} \\
\hat{\lambda} \\
\hat{i}\end{array}$ & 苗 & 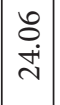 & 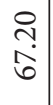 & $\begin{array}{l}+ \\
\infty \\
\infty \\
\infty \\
\infty\end{array}$ & $\begin{array}{l}\hat{b} \\
\dot{f} \\
\end{array}$ & 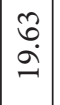 & $\begin{array}{c}\vec{S} \\
\infty \\
\rightarrow \\
-\end{array}$ & \\
\hline & U & 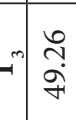 & 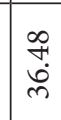 & $\begin{array}{l}\hat{O} \\
\dot{n} \\
\hat{n}\end{array}$ & 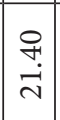 & $\begin{array}{l}\stackrel{n}{\alpha} \\
\vec{\sim}\end{array}$ & $\mid \begin{array}{c}0 \\
2 \\
\infty \\
\infty \\
-1\end{array}$ & $\begin{array}{l}m \\
\infty \\
\dot{m} \\
\dot{m}\end{array}$ & $\begin{array}{l}\tilde{\sigma} \\
\hat{\omega} \\
\stackrel{n}{2}\end{array}$ & $\mid \begin{array}{l}\infty \\
1 \\
0 \\
o+1 \\
+1\end{array}$ & $\begin{array}{c}\infty \\
\stackrel{\infty}{n} \\
\dot{n}\end{array}$ & $\begin{array}{l}\stackrel{\infty}{\sharp} \\
\stackrel{H}{H}\end{array}$ & \\
\hline & & 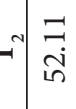 & $\begin{array}{l}8 \\
\dot{q}\end{array}$ & $\begin{array}{l}8 \\
\dot{a} \\
\dot{a}\end{array}$ & $\begin{array}{l}\vec{N} \\
\stackrel{\sim}{\longrightarrow}\end{array}$ & $\begin{array}{l}0 \\
\stackrel{1}{1} \\
2 \\
2\end{array}$ & 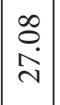 & $\begin{array}{l}\qquad 0 \\
\dot{m} \\
\dot{m}\end{array}$ & 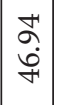 & 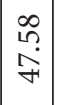 & $\begin{array}{l}\vec{\sigma} \\
\dot{\gamma}\end{array}$ & \begin{tabular}{l}
$\infty$ \\
\multirow{1}{f}{} \\
$\dot{q}$
\end{tabular} & $\begin{array}{l}\text { 苍 } \\
\text { 言 }\end{array}$ \\
\hline & $H$ & 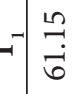 & $\begin{array}{l}\infty \\
\infty \\
\infty \\
\infty\end{array}$ & $\begin{array}{l}\triangleright \\
\infty \\
\dot{m}\end{array}$ & 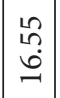 & $\begin{array}{l}8 \\
\stackrel{\sim}{1} \\
\end{array}$ & $\begin{array}{c}\stackrel{2}{2} \\
\stackrel{1}{i}\end{array}$ & $\begin{array}{l}\infty \\
\infty \\
\dot{m}\end{array}$ & \begin{tabular}{|l|}
$\vec{n}$ \\
$\stackrel{\rho}{0}$
\end{tabular} & $\begin{array}{c}\vec{b} \\
\hat{m} \\
m\end{array}$ & $\mid \begin{array}{c}\not \\
\infty \\
\dot{F}\end{array}$ & $\begin{array}{l}\infty \\
\infty \\
\dot{0}\end{array}$ & \\
\hline & -1 & 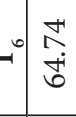 & iñ & $\begin{array}{l}0 \\
\infty \\
i \\
i\end{array}$ & $\mid \begin{array}{l}0 \\
i \\
i \\
i \\
+1\end{array}$ & $\begin{array}{l}\text { ํ. } \\
\dot{+} \\
\dot{m}\end{array}$ & $\begin{array}{l}1 \\
\tilde{n} \\
\dot{m}\end{array}$ & $\begin{array}{l}\stackrel{2}{2} \\
\text { } \\
\end{array}$ & 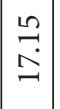 & $\stackrel{\stackrel{\sim}{7}}{\stackrel{+}{ \pm}}$ & $\mid \begin{array}{c}\stackrel{2}{0} \\
\stackrel{n}{n} \\
-\end{array}$ & $\begin{array}{l}0 \\
\stackrel{\mathfrak{I}}{\underline{I}}\end{array}$ & \\
\hline$\frac{0}{0}$ & & 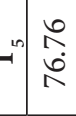 & $\stackrel{\substack{n \\
\infty}}{\infty}$ & $\mid \begin{array}{c}n \\
\tilde{O} \\
i \\
\infty\end{array}$ & 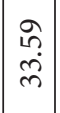 & $\begin{array}{l}\stackrel{p}{ } \\
m \\
\dot{m}\end{array}$ & 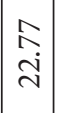 & 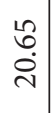 & $\begin{array}{l}o \\
\stackrel{a}{ } \\
\text { i }\end{array}$ & $\begin{array}{l}2 \\
\stackrel{2}{ } \\
\dot{+}\end{array}$ & $\begin{array}{l}\hat{\sigma} \\
\dot{+} \\
\end{array}$ & 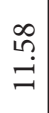 & $\begin{array}{l}8 \\
8 \\
0 \\
0\end{array}$ \\
\hline 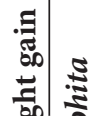 & $\Xi$ & 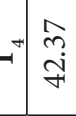 & $\begin{array}{c}m \\
m \\
\stackrel{q}{+}\end{array}$ & 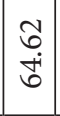 & $\mid \begin{array}{c}\tilde{T} \\
1 \\
\infty \\
0 \\
0\end{array}$ & $\mid \begin{array}{l}a \\
\dot{b} \\
\dot{f}\end{array}$ & $\begin{array}{l}2 \\
\dot{\sigma} \\
\dot{\sim}\end{array}$ & $\begin{array}{l}\stackrel{0}{\cdots} \\
\stackrel{m}{m}\end{array}$ & 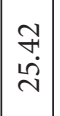 & 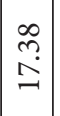 & $\begin{array}{c}n \\
m \\
\ddot{n}\end{array}$ & $\underset{\infty}{\mathbb{\infty}}$ & (3) \\
\hline 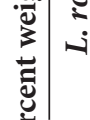 & $-i \mid$ & 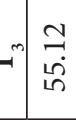 & $\vec{\sigma}$ & $\mid \begin{array}{c}1 \\
\hat{i} \\
\grave{i}\end{array}$ & $\vec{F}$ & $\begin{array}{l}0 \\
\dot{\dot{m}} \\
\end{array}$ & $\mid \begin{array}{l}n \\
\infty \\
\dot{m} \\
\dot{m}\end{array}$ & $\begin{array}{l}\hat{m} \\
\dot{m} \\
\dot{m}\end{array}$ & \begin{tabular}{|l|}
$\stackrel{m}{+}$ \\
$\dot{m}$ \\
$m$
\end{tabular} & $\begin{array}{c}0 \\
\stackrel{0}{2} \\
\stackrel{m}{m}\end{array}$ & $\begin{array}{c}0 \\
0 \\
\infty \\
\infty \\
n \\
\end{array}$ & 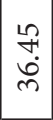 & \\
\hline & $H$ & 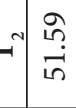 & $\begin{array}{l}\vec{\sigma} \\
\hat{\delta} \\
\tilde{e}\end{array}$ & $\begin{array}{c}+ \\
\infty \\
\dot{m} \\
\dot{n}\end{array}$ & 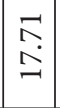 & ㄱ. & $\begin{array}{l}\text { aे } \\
\dot{i}\end{array}$ & $\stackrel{m}{m}$ & $\mid \begin{array}{l}0 \\
م \\
n \\
n\end{array}$ & $\begin{array}{c}\infty \\
\stackrel{\infty}{+} \\
\dot{f}\end{array}$ & $\mid \begin{array}{c}\stackrel{n}{p} \\
\stackrel{\alpha}{q}\end{array}$ & $\begin{array}{l}\vec{H} \\
\text { in } \\
\text { ñ }\end{array}$ & $\sum_{00}^{\pi}$ \\
\hline & $F$ & $=\begin{array}{l}n \\
\stackrel{n}{n} \\
n \\
n\end{array}$ & $\begin{array}{l}\tilde{O} \\
\hat{i} \\
i\end{array}$ & $\begin{array}{c}\stackrel{7}{7} \\
\dot{q}\end{array}$ & $\stackrel{\circ}{\stackrel{\circ}{+}}$ & $\begin{array}{l}\overrightarrow{2} \\
\stackrel{2}{\sigma}\end{array}$ & $\begin{array}{l}\infty \\
\stackrel{\sim}{0} \\
\sim\end{array}$ & $\begin{array}{l}\stackrel{0}{\infty} \\
\stackrel{m}{m}\end{array}$ & $\begin{array}{c}\hat{n} \\
\hat{n} \\
\text { n. }\end{array}$ & $\mid \begin{array}{c}n \\
\hat{n} \\
i q \\
q\end{array}$ & \begin{tabular}{c}
1 \\
\multirow{6}{b}{} \\
+1
\end{tabular} & \begin{tabular}{l}
10 \\
$\infty$ \\
\multirow{4}{*}{} \\
\end{tabular} & \\
\hline & -1 & $=\frac{\mathscr{c}}{2}$ & 壱 & $\mid \begin{array}{l}0 \\
\stackrel{0}{0} \\
\stackrel{+}{1}\end{array}$ & $\mid \begin{array}{l}0 \\
0 \\
0 \\
\dot{q} \\
+1\end{array}$ & 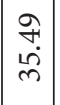 & $\begin{array}{l}\hat{\sigma} \\
\stackrel{\hat{\nu}}{2}\end{array}$ & $\underset{\vec{n}}{\vec{n}}$ & $\begin{array}{l}+ \\
\stackrel{i}{\hat{~}}\end{array}$ & $\mid \begin{array}{l}\infty \\
\infty \\
\\
\end{array}$ & $\stackrel{2}{\stackrel{2}{2}}$ & 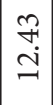 & \\
\hline & $H^{\prime \prime}$ & $=\frac{a}{\Delta}$ & 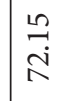 & $\mid \begin{array}{c}0 \\
\tilde{i} \\
\infty \\
\infty\end{array}$ & $\underset{⿱ 亠 䒑}{\stackrel{+}{+}}$ & $\begin{array}{l}0 \\
\stackrel{0}{0} \\
\stackrel{\vec{D}}{1}\end{array}$ & $\underset{\vec{\sim}}{\stackrel{\sim}{\sim}}$ & $\begin{array}{l}\widehat{\widehat{\lambda}} \\
\stackrel{\mathrm{i}}{2}\end{array}$ & $\begin{array}{l}\underset{\sim}{\sim} \\
\vec{i}\end{array}$ & $\underset{\vec{i}}{\stackrel{+}{a}}$ & 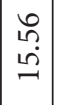 & $\begin{array}{l}0 \\
\stackrel{2}{0}\end{array}$ & $\|^{m}$ \\
\hline & $\stackrel{\mathrm{z}}{\mathrm{z}}$ & $-=\stackrel{\vec{m}}{\stackrel{m}{q}}$ & 完 & 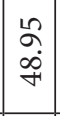 & $\mid \begin{array}{c}\tilde{N} \\
\tilde{b} \\
\dot{b}\end{array}$ & $\begin{array}{l}8 \\
\text { i } \\
\text { | }\end{array}$ & $\begin{array}{l}\infty \\
\stackrel{\infty}{0} \\
i \\
\text { in }\end{array}$ & $\begin{array}{l}= \\
\vec{m} \\
m\end{array}$ & 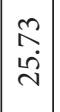 & $\begin{array}{c}\tilde{\alpha} \\
\alpha \\
-\infty\end{array}$ & 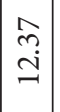 & $\begin{array}{l}\infty \\
\infty \\
\infty \\
\infty\end{array}$ & $\overbrace{b 0}$ \\
\hline & تص & 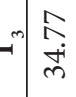 & $\begin{array}{l}0 \\
\text { in } \\
i \\
m\end{array}$ & $\mid \begin{array}{l}R \\
0 \\
\dot{m}\end{array}$ & $\mid \begin{array}{c}\hat{b} \\
\stackrel{i}{i}\end{array}$ & 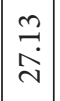 & $\mid \begin{array}{l}0 \\
0 \\
0 \\
\dot{d}\end{array}$ & $\begin{array}{l}\stackrel{q}{0} \\
\stackrel{m}{m}\end{array}$ & $\begin{array}{l}\hat{\infty} \\
\infty \\
\dot{m}\end{array}$ & $\begin{array}{l}\tilde{\sigma} \\
\stackrel{m}{m}\end{array}$ & $\begin{array}{c}\hat{n} \\
\hat{n} \\
\hat{n}\end{array}$ & 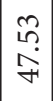 & 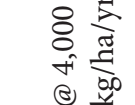 \\
\hline & $H$ & 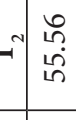 & $\underset{\vec{c}}{\stackrel{\sigma}{\infty}}$ & $\mid \begin{array}{l}\infty \\
\alpha \\
i n \\
n\end{array}$ & 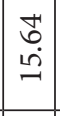 & 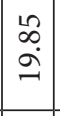 & $\mid \begin{array}{c}\exists \\
\vec{\lambda} \\
\stackrel{\sim}{*}\end{array}$ & $\begin{array}{l}\overrightarrow{\hat{\lambda}} \\
\stackrel{\mathrm{i}}{2}\end{array}$ & $\begin{array}{l}0 \\
\infty \\
\dot{m} \\
\dot{\alpha}\end{array}$ & $\left|\begin{array}{l}0 \\
b \\
\dot{q} \\
+1\end{array}\right|$ & $\left|\begin{array}{c}\tilde{n} \\
\hat{q} \\
q\end{array}\right|$ & $\begin{array}{l}\stackrel{2}{\hat{\alpha}} \\
\stackrel{+}{q}\end{array}$ & 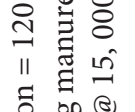 \\
\hline & $F$ & 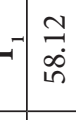 & $\begin{array}{l}8 \\
\dot{9}\end{array}$ & $\begin{array}{l}o \\
\infty \\
\dot{f} \\
\dot{f}\end{array}$ & 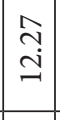 & $\begin{array}{l}\hat{\sigma} \\
\stackrel{2}{\sigma}\end{array}$ & $\mid \begin{array}{l}\vec{\alpha} \\
\dot{\nu}\end{array}$ & $\begin{array}{l}\stackrel{8}{ } \\
\stackrel{\infty}{ } \\
m\end{array}$ & $\mid \begin{array}{c}r \\
0 \\
\dot{d} \\
⿱ 亠\end{array}$ & $\begin{array}{c}\vec{F} \\
\overrightarrow{+} \\
\stackrel{2}{+}\end{array}$ & $\underset{\underset{H}{+}}{\stackrel{H}{+}}$ & $\begin{array}{l}\hat{N} \\
\hat{b} \\
\dot{f}\end{array}$ & 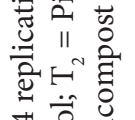 \\
\hline & : & $\overline{0}$ & $\vec{z}$ & $A$ & Еं & $\mathbf{L}$ & 峛 & $\dot{4}$ & $\stackrel{\vec{\pi}}{\Sigma}^{\mathrm{a}}$ & छ & 齐 & $\frac{\infty 00}{4}$ & 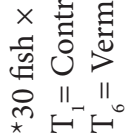 \\
\hline
\end{tabular}




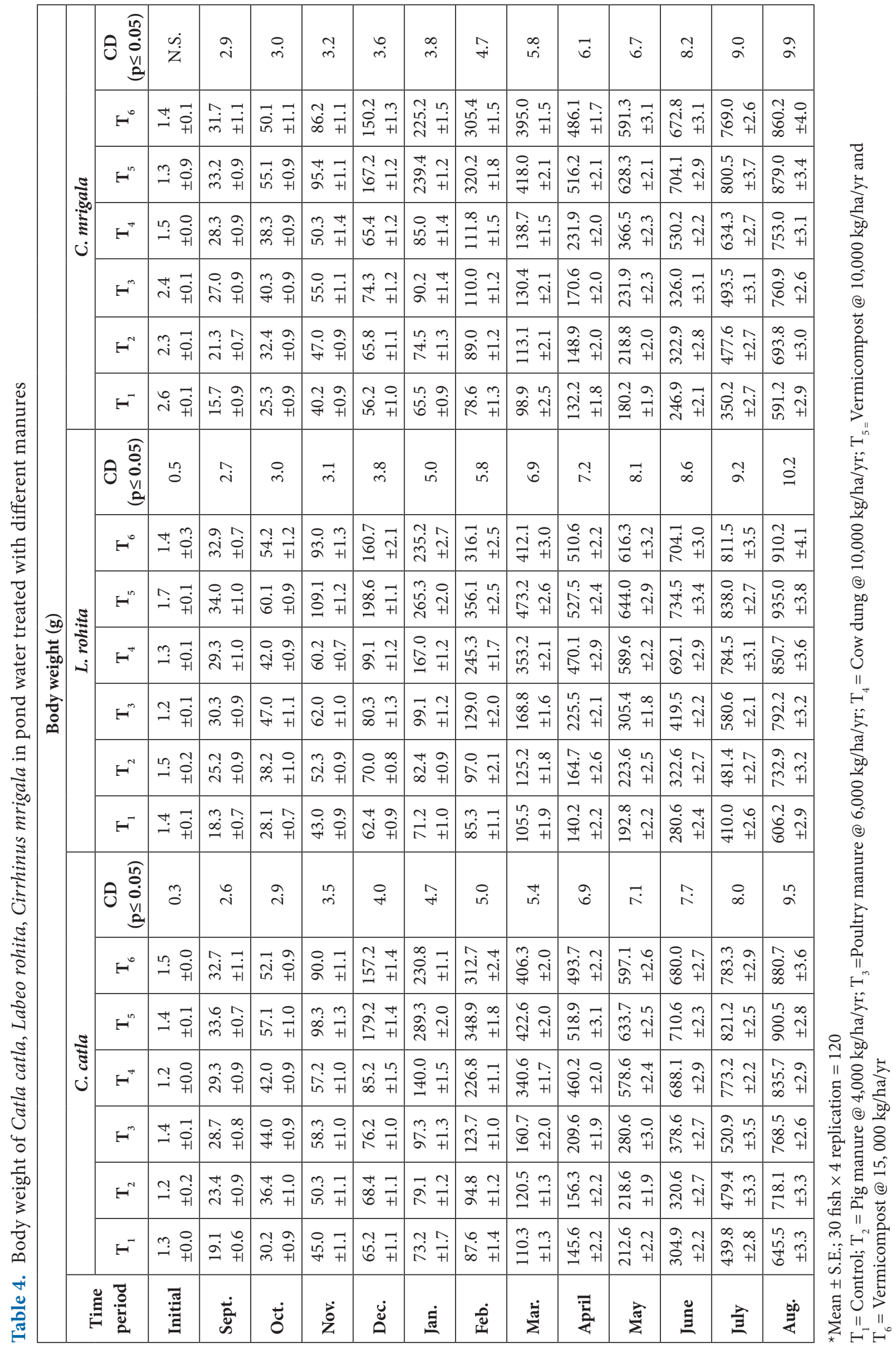


The gain in the live body weight of $L$. rohita in vermicompost @ $10.000 \mathrm{~kg} / \mathrm{ha} / \mathrm{yr}$ was observed to be maximum with 933.3 followed by 908.8 in vermicompost @ 15,000 kg/ha/yr, 849.4 in cow dung @ 10,000 kg/ha/yr, 791.0 in poultry manure @ $6,000 \mathrm{~kg} / \mathrm{ha} / \mathrm{yr}$ and then $731.4 \mathrm{gm}$ in pig manure @ 4,000 kg/ ha/yr. Above all these five treatments were found to have more growth promoting effect over the $604.8 \mathrm{gm}$ in control (Table 4). Maximum weight was attained by L. rohita followed by $C$. catla and C. mrigala. Among the six different treatments vermicompost @ $10.000 \mathrm{~kg} / \mathrm{ha} / \mathrm{yr}$ was the best treatment in which maximum growth of Indian major carps was attained followed by cow dung $>$ poultry manure $>$ pig manure Bahkta et al. (2004) worked on mixed poultry dropping, cattle manure, single super phosphate, urea and observed that at optimum level of $422 \mathrm{gm} / \operatorname{tank} /$ week fertilization, the carps show maximum yield. The best growth among used manures were observed in vermicompost @ 10,000 kg/ha/yr followed by cow dung @ $10,000 \mathrm{~kg} / \mathrm{ha} / \mathrm{yr}$, poultry manure @ 6,000 kg/ha/yr, pig manure @ 4,000 kg/ha/yr and control. It is concluded from these results that organic manures have a significant advantage over inorganic fertilizers similar results were concluded by Sumitra et al. (1981).

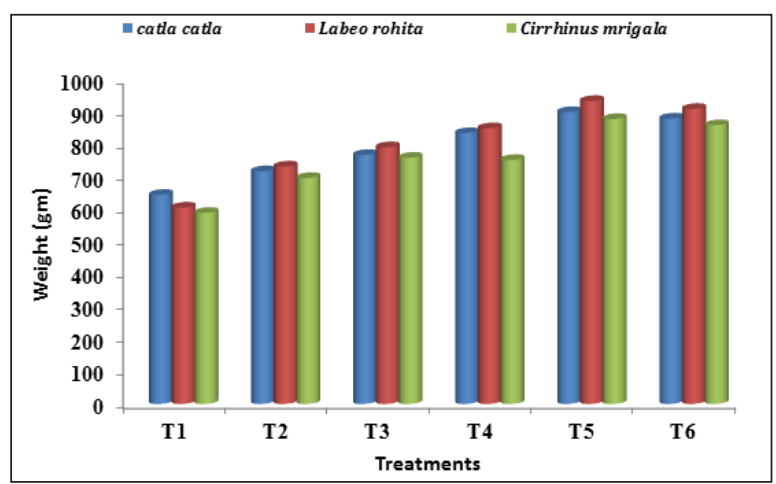

Figure 1. Weight of three fish species in pond water treated with different manures.

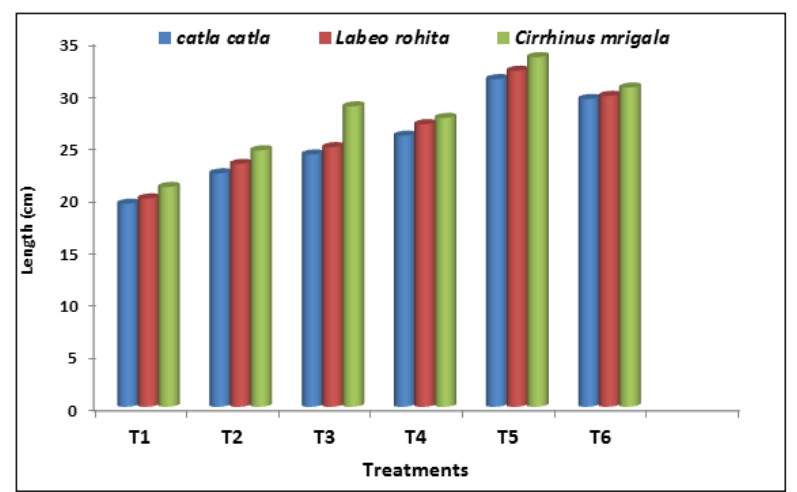

$\mathrm{T}_{1}=$ Control, $\mathrm{T}_{2}=$ Pig manure @ 4,000 kg/ha/yr, $\mathrm{T}_{3}=$ Poultry manure @6,000 kg/ha/yr, T $=$ Cow dung@ 10,000 kg/ha/yr, $\mathrm{T}_{5}=$ Vermicompost@10,000 kg/ha/yr, T6=Vermicompost @15,000 $\mathrm{kg} / \mathrm{ha} / \mathrm{yr}$

Figure 2. Length of three fish species in pond water treated with different manures.

\section{Acknowledgements}

Authors are thankful to Principal, CRM Jat P. G. College for providing necessary facilities.

\section{References}

1. APHA. Standard methods for the examination of water and waste water. 19th Ed. Washington, DC: American Public Health Association; Aquaculture Research. 1998; 37:1360-71.

2. Azad MAK, Rahman MR, Rahman Z, Kader MA. Haque MM, Alam MJ. Polyculture of carps, tilapia and pangas using low cost inputs. Pakistan Journal of Biological Sciences. 2004; 7(11): 1918-26. https://doi.org/10.3923/pjbs.2004.1918.1926

3. Banergae RK, Ray P, Singit GS, Dutta BR. Poultry droppings: Its manorial potentiality in aquaculture. Journal of Inland Fisheries Society of India. 1979; 2(10):94-108.

4. Bansal N. Effect of vermicompost as pond fertilizer on growth performance of common carp (Cyprinus carpio Linn.). [M.Sc. Thesis]. Dept. of Zoology, CCSHAU: Hisar; 2010. p. 43.

5. Bhakta JN. Fertilizer-microbial interaction in waste water system, influence of fertilizer dose and stocking density of fish. [Ph. D. Thesis]. University of Kalyani: India; 2003. p. 188.

6. Bhakta JN, Bandyopadhyay PK, Jana BB. Effect of different doses of mixed fertilizer on some biogeochemical cycling bacterial population in carp culture pond. Turkish Journal of Fisheries and Aquatic Sciences. 2006; 6:165-71.

7. Bhakta JN, Sarkar D, Jana S, Jana BB. Optimizing fertilizer dose for rearing stage production of carp under polyculture. Aquaculture. 2004; 23(9):125-39. https://doi.org/10.1016/j. aquaculture.2004.03.006

8. Chakrabarti NM. Biology, culture and production of Indian major carps. Fisheries Scientist in Indian Council of Agricultural Research; 1998. p. 175.

9. Chatterjee DK, Saha PK. Effect of organic manures on organic carbon contents of submerged pond soil. Bamidgeh. 2000; 52(3):118-26.

10. Conte FS. Pond fertilization: Initiating an algal bloom. Technical Bulletin No.104. Western Regional Aquaculture Centre, Alaska. Arizona. California. Colorado. Idaho. Montana. Nevada. New Mexico. Oregon. Utah. Washington. Wyoming; 2000. p. 1-9.

11. Deolalikar AV, Mitra A. Effect of vermicompost on growth of fish Labeo rohita (Hamilton). Journal of Aquaculture in Tropics. 2004; 19:63-79.

12. Garg SK, Bhatnagar A. Effect of fertilization frequency on pond productivity and fish biomass in still water ponds stocked with Cirrhinus mrigala (Ham.). Aquaculture Research, 2000; 31:40914. https://doi.org/10.1046/j.1365-2109.2000.00422.x

13. Goolish EM, Adelman RR. Effect of ration size and temperature on the growth of juvenile common carp (Cyprinus carpio). Aquaculture. 1984; 26:27-35. https://doi.org/10.1016/00448486(84)90051-6

14. Javed M. Growth performance and meat quality of major carps as influenced by pond fertilization and feed supplementation. [Ph.D. Thesis]. Dept of Zoology and Fisheries: Agriculture University of Faisalabad, Pakistan; 1988. p. 298. 
15. Javed M, Sajid A. Studies on the growth performance of major carps under integrated semi-intensive culture system Indus. Journal of Biological Series. 2005; 2(2):254-9.

16. Javed M, Hassan M, Javed K. Fish pond fertilization (IV): Effect of artificial feed on the growth performance of major carps. Journal of Pakistan Agricultural Sciences. 1993; 30:7-12.

17. Javed M, Sial MB, Javed K. Effect of artificial feed on the growth performance of major carps. Pakistan Journal of Agricultural Sciences. 1990; 30(2):167-72.

18. Jena J, Das PC, Mondal S, Das R. Compatibility of silver barb, Puntius gonionotus (Bleeker) with Indian major carps in a growout polyculture. Aquaculture Research. 2007; 38:1061-5. https:// doi.org/10.1111/j.1365-2109.2007.01768.x

19. Kaur JS. Impact of vermicompost as pond fertilizer on the growth performance of Indian major carps. [M.Sc. Thesis]. Dept of Zoology: CCSHAU, Hisar; 2011. p. 50.

20. Kaur VI, Ansal MD. Efficacy of vermicompost at fish pond manure, its effect on water quality and growth of Cyprinus carpio (Linn.). Bioresource Technology. 2010; 101(15):6215-8. https:// doi.org/10.1016/j.biortech.2010.02.096

21. Kumar P, Sagar V, Choudhary AK, Kumar N. Vermiculture: Boon for fish farmers. Fish Chimes. 2007; 27:40-2.

22. Miah MS, Shab Uddin M, Shah MS. Effects of artificial feed in carps polyculture system. Bangladesh Journal of Agriculture Sciences. 1993; 20:359-64.

23. Natarajan M, Varghese TJ. Studies on the effects of poultry manure, digested sewage sludge cake, cow dung on the growth rate of Catlacatla (Ham.) and Cyprinus carpio var. communis (Linneaus). Agricultural Wastes. 2003; 2(4):261-71. https://doi. org/10.1016/0141-4607(80)90003-7
24. Nath SS, Lannan JE. Dry matter-nutrient relationships in manures and factors affecting nutrient availability from poultry manures. Egna H, McNamara M, Bowman J, N. Astin, Editors. Tenth Annual Admin Report, 1991-1992. PD/A CRSP, Office of International Research and Diversity, Corvallis, Oregon; 1992. p. $110-9$.

25. Ram NM, Zur O, Avnimelech Y. Microbial changes occurring at sediment-water interface in an intensively stocked and fed fish pond. Aquaculture. 1982; 27:63-72. https://doi. org/10.1016/0044-8486(82)90110-7

26. Rappaport V, Sarig S. The results of manuring on intensive growth fish farming at the Ginosar station (Israel) ponds. Bannidgeh. 1978; 30(2):27-30.

27. Snedecor G, Cochran W. Statistical method (8th ed). The IOWA State University Press; 1989. p. 502.

28. Sumitra V, Kumari KL, Gropineth V, Bhawan RM. Aquaculture of pear spot (Elroplusauratenis) in an esturine pond; environmental characteristics, primary reduction, growth benefit ratio. Indian Journal of Marine Science. 1981; 10:82-7.

29. Wurts WA. Sustainable aquaculture in the twenty first century. Reviews in Fisheries Science. 2004b; 8:141-50. https://doi. org/10.1080/10641260091129206

30. Yadava NK, Garg SK. Relative efficacy of different doses of organic fertilizer and supplement feed utilization under intensive fish farming. Bioresoure Technology. 1992; 42(1):61-5. https:// doi.org/10.1016/0960-8524(92)90088-F 